\title{
Finding the right spouse: Young Sri Lankan Tamil Hindu women in Denmark
}

\author{
MARIANNE QVORTRUP FIBIGER' \\ Aarhus University, Denmark
}

\begin{abstract}
This article focuses on second-generation, well-educated Sri Lankan Tamil Hindu women whom now live in the university towns of Denmark. After leaving their parents' homes in Denmark, they have begun to speak out, criticising matters concerning the Tamil Hindu tradition that they believe conflict with their lives in modern Danish society, both as Tamil Hindus, and as women. At the same time, they emphasise elements within the same tradition that, from their point of view, are so important, they want to pass them on to the next generation. This contradiction or conflict between connecting and disconnecting to tradition becomes obvious with regard to the discussion of finding the right spouse, where the young Sri Lankan Tamil Hindu women are caught in a conflict between following their parents marriage patterns and requirements with respect to including caste or kinship, or following their new effort to find an equally educated husband no matter of caste affiliation. This article gives examples from this discussion, which I have followed on the Internet over the last couple of years, supplemented with about 50 semi-structured interviews with young, second-generation, Sri Lankan Tamil Hindus.
\end{abstract}

\section{Keywords}

Cultural or collective memory, cultural hybridity, identities, generation conflict, gender

\section{Introduction}

In Denmark, there are about 11,500 people of Sri Lankan origin, of which approximately 10,000 are Tamil Hindus. ${ }^{2}$ The first Sri Lankan Tamil Hindus came to Denmark in 1983 because of the escalating conflict in Sri Lanka. They were mostly men and categorized as de facto refugees. During the 1990s, they were reunited with the families they left behind, or they married Sri Lankan Tamil women, and began to settle down.

\footnotetext{
${ }^{1}$ She is an associate professor of religious studies at Aarhus University. Her work focuses on Hinduism in general (in Denmark and in the diaspora, in particular), ktism, religious plurality and diversity, how concepts and worldviews travel between East and West, and religion in cultural encounters.

2 Because Statistics Denmark, which registers all newcomers to Denmark, do not take religious, but only geographic affiliation into account, it is difficult to give an exact figure when it comes to religious grouping. In Sri Lanka, the Tamils are, and always have been, a minority group. According to the 2012 census, the total population of Sri Lanka is 20.2 million people, of which the major ethnic group (up to $75 \%$ ) is the Sinhalese, mostly Buddhist; then comes the Tamils, comprising about $15 \%$ of the population, divided between Sri Lankan Tamils (approximately 11\%) and Indian Tamils (approximate 4\%), most of which are Hindus.
} 
This article focuses on how they balance between being part of a presumed, shared, Tamil cultural heritage or cultural memory, and at the same time, being part of Danish society. This article gives examples from this discussion, which I have followed on the Internet over the last couple of years, supplemented with about 50 semi-structured interviews with young, second-generation, Sri Lankan Tamil Hindus. Theoretically, this article both takes advantage of, and contests, the theories of cultural hybridity and third space (Homi Bhabha 1994). It is my conviction that even if the intention, when introducing these theories, was to criticise a static and essentialist idea of ethnicity, identity, and culture in a migratory and diasporic setting, they still support it. Therefore, I supplement the notions of hybridity and third space with the idea of a 'translocal positionality', as developed by Floya Anthias (2001), emphasising that 'identities' are located outside old ethnicities and localities. This is a fact even though, which my case study shows, that these are still understood by their constructors (in this case, second-generation Tamil Hindu women) as being something worth keeping in a new form, suitable for modern women in Denmark: here, the Tamil language and the temple, understood as a religious and cultural preservers, seem to be given particular importance. This statement does not imply that culture is not constructed (individuals are not passive recipients), however, it does suggest that such a construction is based on at least two aspects. First, it is based on specific socialisation within a family that is affiliated with a particular group - be it ethnic, cultural, religious, or connected through shared values - to which the individual is introduced, and in which he/she has to act accordingly (by partially adopting, fully adopting, or rejecting these values). Second, it is based on the conferred flexibility or elasticity within the same tradition that a group of individuals understand as shared, in this article, labelled 'cultural' or 'collective' memory (Assmann 2006; Hervieu-Léger 2000).

\section{Background of Tamil movement}

Although a full description of the conflict cannot be given here, it is important to point out the escalation of pogroms and riots during the 1970s, ending with the so-called 'Black July' of 1983, when Tamil shops were burned, and the slogan, 'Sinhala only' (referring to the Sinhala language) was heard in the streets. Consequently, the Tamil militant group, The Liberation Tigers of Tamil Eelam (LTTE), also called the Tamil Tigers, increased their fight for an independent state in the northeast part of Sri Lanka. This very well organised militant group, equipped with both an air force and a navy, but especially known for having had a charismatic leader, Velupillai Prabhakaran (1954-2009), and around 10,000 well-trained soldiers and child soldiers, was both supported and feared among the Tamil minority group in Sri Lanka (Swamy 1994; Amarasingam 2015). The LTTE 
was supported because most Tamils sympathised with the fight for Tamil equal rights, including the right to speak and use the Tamil language in every aspect of life. But at the same time LTTE was also feared, because most Tamils did not like their methods, and the way they recruited soldiers for its army, which was often a forced duty (Swamy 2003). This launched a wave of Tamil refugees. In the beginning they were mostly men who wanted to escape recruitment by the LTTE or to be imprisoned by the Sinhala government troops, who saw the young Tamil men as possible LTTE sympathizers, and therefore as a threat.

Today, more than 8,000 of the approximately 11.500 Sri Lankan Tamils living in Denmark have become Danish citizens. This shows their sincere wish to settle down in Denmark permanently. Compared to most other refugee and immigrant groups in Denmark, the Sri Lankan Tamils are, according to seven criteria's formulated by a so called "Think-tank" set-up by the government year 2000 and still used as a parameter to day (see the Ministry of Justice Website 2015). ${ }^{3}$ They are well integrated into Danish society: most of them work, their children, especially the girls, are doing well in the Danish schools, and they often choose to speak Danish to one another. In other words, they have passed through an adaptation process much more quickly than many of the other immigrant and refugee groups in Denmark (see Denmarks statistics 2014). However, although they wish to stay in Denmark, they do not wish to lose their relationship to Sri Lanka, which they still regard as some kind of homeland. Therefore, in this sense, ethnicity relates to both homeland and to the society in which they have settled; at the same time, this shows how the relationship between the old and the new homeland is dialectic and constantly reconfigured.

In this process of adaptation, they are especially reluctant to lose their connection to Tamil Hinduism, which they continue to understand as a form of translocal identity marker. The six Sri Lankan Hindu temples in Denmark are a testament to this. ${ }^{4}$ An elderly Sri Lankan Tamil Hindu told me, back in 1994, when the first Tamil Hindu temple in Denmark was consecrated: 'Now I really feel at home in Denmark, too'. This statement shows that religion, at least in this case, seems to transcend place of settlement. This does not mean that the Tamil Hindu religion is not changing in the new settlement in Denmark, and it does not mean that new

\footnotetext{
${ }^{3}$ The Ministry of Justice. In 2011 the government imposed the Ministry of Integration and integrated it in three other ministries - among them the Ministry of Justice

4 Unfortunately, the scope of this article does not extend to a discussion of the role of religious organisations as tradition keepers, and in the social integration of immigrants. Regarding the latter, Breton identifies at least four ways in which religion may assist; it may: a) provide practical services and social opportunities; b) foster social and civic participation; c) make available cultural tools to cope with the moral challenges encountered in the new cultural milieu; and d) offer a paradigm by which the new society is defined by members of the group (Breton 2012: 97).
} 
elements within Danish culture are not taking into account and supplementing or succeeding parts of the Tamil religious or cultural tradition, but the religious institution as a concrete, visible sign in the new setting seems to be given particular importance.

The second generation of Sri Lankan Tamils in Denmark, who were either born in Denmark or came to Denmark as small children, also feel that the old homeland and the Hindu religion matter, but they are struggling to connect to both the old homeland and the new, and to the Hindu religion. As expressed by a 25-year-old woman (asked Where do you feel you belong?), this seems to depend on the situation and the location and an example of translocality:

It really depends on where I am. When I am asked at home [Denmark], I answer either Sri Lanka or Struer [city in Denmark]. When asked abroad, I tell them I am from Denmark. (Sri Lankan Tamil Hindu, female, 25 years).

When it comes to cultural adaptation, an increasing number of Sri Lankan Tamils are adopting selected Danish traditions (for example, Christmas Eve), but on their own terms. A Sri Lankan Tamil Hindu father 40 years of age remarked:

We do celebrate Christmas with presents and a Christmas tree, decorated with things our children make at school, in our living room, but we don't sing Christmas Carols or go to church. Some of our Tamil friends in Germany go to church, but we have decided not to. We think it is important that our children have a relationship to our temple, instead. It's not that they are not allowed in church - they go there with the school-but just for them to get an idea of where our tradition comes from, or is strongly connected.

This inclusion of elements from the Danish tradition and culture also makes Tamil Hindus more aware of what they consider the important hallmarks associated with being Hindu and Tamil, and it provides us not only with an interesting example of how inclusiveness and exclusiveness related to tradition or culture may mutually affect each other, but also, how these hallmarks are under constant negotiation, and changes related to context, or to what these hallmarks are understood as being hallmarks of. This is true, even if the motivation for adapting to westernised and Christian forms is to achieve greater respectability among the majority, as observed by Vertovec while investigating Hindus in Trinidad (Vertovec 1990: 232). At the same time, the Danish Christmas Eve reminds The Tamil Hindus in Denmark of Divali, the most important festival for many Hindus - in some ways, this may be called the transference of one religious celebration to another. At the same time, the outcome is both something new and something recognisable. As one Sri Lankan Tamil Hindu, woman, 50 years of age, told me: 
I compare your Christmas to Divali. The first thing that comes to my mind is the decoration and lighting. Divali is a festival of lights. So most of the houses are decorated with lights. Also, we also make very delicious food items, just like here. We also set off lots of firecrackers.

Today, the Sri Lankan Tamil Hindus are scattered over most of Denmark in small groups that are anchored in many different localities. Some have moved following new job opportunities, while those belonging to the second generation of Tamils have moved to the capital, Copenhagen, or other university towns, such as Aarhus, in pursuit of higher education. Especially the Tamil young women have done well in the Danish secondary school system, and have now started a university education. In general, around 67 per cent of all Tamils in Denmark are fully employed, which means that, together with the Indians and the Vietnamese, they have the largest rate of employment of all immigrant (and refugee) groups in Denmark. Also, the educational level among young Tamils is high, compared to other groups, which can be noticed in statistic material published every year on Denmark (Denmarks Statistic 2014). One reason for this is found in the very strong work ethic that seems to be implicit in the Hindu tradition, and consequently, the children are raised in an atmosphere where education matters. In my interviews it becomes clear that education is not only understood as an instrument for doing well in society but is also a kind of token or offering to God fulfilling the possibilities given by God. This is at least what one of my informants a 55-year-old, first-generation Sri Lankan Tamil Hindu father emphasises to me:

I have raised my children to understand the importance of education. They have opportunities in Denmark for education that I myself didn't have in Sri Lanka - they just have to fulfil them - from my point of view, God-given possibilities.

\section{Multiple identities}

Cultural interchange and the conflict between criticism of an imagined, shared tradition, and using it as a reservoir for legitimising a new view on life and gender relations, becomes especially profound among secondgeneration Sri Lankan Tamil Hindu women who have started a longer university programme and now live in the university towns of Denmark. They have begun to speak out, criticising matters within the Tamil Hindu tradition that they believe contradict their lives in modern Danish society, both as Tamil Hindus, and as women. That is at least what I have noticed in my research within the last couple of years. This does not mean they are dismantling their tradition; instead, which become clear in my interviews, they are using elements or arguments somehow supported by tradition to overrule others within the tradition that are not compatible to their new strive in life here in Denmark. A crucial example is how they use education 
or their implicit work ethic as an argument for overruling caste as the main criterion when seeking a husband. So, although a permanent reinterpretation process is going on within the whole group, I find a generation gap, as well as a gender gap, in this process. In their selfunderstanding, they all seem to emphasise being both Tamil and Hindu, but in many respects, what they put into these categories seems to differ. This is of course the case for every individual, and changes according to circumstances and situation, but an overall pattern may be noted when comparing the first and second generations. Whereas first-generation Tamil immigrants generally try to keep up the traditions, explicitly as they know them from Sri Lanka, second-generation immigrants do not (Fibiger; 2011). They reinterpret or pick out the specific elements of what is understood as important parts of an imagined tradition, but in a translated or reinterpreted form, which helps them to engage in the society of which they are now a part, and at the same time links them to the imagined tradition they share with their parents.

The idea of a mutual, shared tradition is particularly vulnerable and profound in relation to new generations that are struggling with not only their hybrid, but also translocal identities, including the identity of being both Danish and Sri Lankan Tamil Hindu on new terms, without the opportunity to anchor their cultural, ethnic, social, or religious identity to a specific place or space, as a specific homeland.

This conflict of linking and unlinking is something the second generation of Sri Lankan Tamil Hindus share with all young immigrants living as minorities in a diaspora situation, but as I state, the Hindu tradition, which on the one hand is very closely linked to right conduct but on the other very difficult to define seems to contribute with arguments that fit both the idea of belonging to a specific tradition, but on the other also provides arguments that fit the lives of well-educated, modern, second-generation, Tamil Hindu women in Denmark or wherever they want to settle down later in their lives. When it comes to the last point, yoga, guruism and God as an entity within oneself is often highlighted among my informants as core elements within their religious tradition.

The strive for balancing between belonging to a tradition but at the same time adapting it to their lives in Denmark also becomes obvious when it comes to gender matters. Here the content of the concept stree-dharma (stree $=$ 'woman', dharma $=$ 'duty') has raised a debate on how to find a spouse for a modern woman with a Tamil Hindu background, in Denmark, still bearing in mind the idea that her duty is to become a mother, and to raise her children without disconnecting them from the idea of a mutuallyshared tradition. The answer is most often a man with a Tamil Hindu 
background who is equally educated. This is expressed for example in the following quotation:

For me it is about the balance between our Tamil background and our Danish upbringing. I try to combine the good things from both cultures. I would like to have a husband who thinks the same, also in relation to the upbringing of children, in relation to education, values, religion, boys/girls, alcohol etc. (Sri Lankan Tamil Hindu, woman, 24 years of age).

They are openly caught in a conflict between following their parents' marriage patterns with respect to caste or kinship, and following their new desire to find an equally well-educated husband, without losing the possibility of connecting their children to the tradition they understand as an important identity marker, and also as an important resource in many life matters. However, despite their open-minded criticism of the way they were raised by their parents and of parts of the Tamil Hindu tradition, most of them emphasise their roles and duties as caretakers and transmitters of tradition. This may be the main reason for questioning a marriage with a man of Danish descent. ${ }^{5}$ This is also what the following statements by second-generation Sri Lankan Tamil Hindu women indicate:

Hinduism doesn't take up much space in my daily life, but it is still part of my identity, and it is my wish to keep up traditions, for example, in relation to marriage and raising my children. I feel I have a duty (out of respect for the tradition) to keep up the relationship to Tamilness and to Hinduism, but out of loyalty, not as a forced duty (Sri Lankan Tamil Hindu, woman, 27 years of age).

Another woman also added that:

I don't want my children to become rootless. I do have roots here, but anyway. The Tamil language, but also the Hindu temple, must play a role (Sri Lankan Tamil Hindu, woman, 24 years of age).

In these statements, it becomes obvious that these young Tamil women attach meaning to the idea of a mutually-shared tradition, but what is of special interest to me as a scholar of the Hindu religion is to understand why or which elements of the tradition the young Tamil Hindu women attach such great importance to that they want to preserve and pass it on to the next generation. Furthermore, they relate these traditions to their selfunderstanding and striving for what they believe is the 'ideal life'.

As stated before, this particular group shares many of the same problems of other young, second- and third-generation immigrant women in Denmark or in the diaspora in general (identity construction, dual belonging,

\footnotetext{
${ }^{5}$ Various surveys and research on Hindu women's roles in the diaspora emphasize how Hindu women have an important role as cultural/religious caretakers and transmitters (Hole 2001; Knott 1996, 2000; Lourenco 2011; Rayaprol 1995, 1997).
} 
generational conflicts, gender conflicts, cultural hybridisation, relation to tradition, multiple identities, etc.), but additionally, this article states that these processes are also shaped in a particular way by being Sri Lankan Tamil Hindu woman in Denmark. This negotiation between being Hindu (religious identity), and Tamil (cultural, ethnic, and social identities), as well as being a Danish citizen (social and cultural identities) is constantly present, and even if constructed, shapes their particular understanding of belonging, not only to a place in history or in the world, but also in the mind. What I find interesting is that they do not seem to want to let go of any of these anchoring points, and they appreciate this form of cultural hybridity. They understand all elements to be important resources, which seems to be the main reason for wanting a Sri Lankan Tamil Hindu husband, a man that shares the same relationship to the above-mentioned elements of belonging. Or, as expressed by a second-generation Sri Lankan Tamil Hindu, woman, 26 years of age:

I would like to get married to a Tamil Hindu, who lives and was raised here
in Denmark. The reason for this wish is that we would understand each
other: for example, in relation to lifestyle (relationship between man and
woman, independence, work) and interests (concerts, go out to a dance,
drink a cold beer, travel). At the same time, we would share a common idea
of belonging, as being both Tamil and Hindu. I think that will help us when
raising our children.

\section{Cultural memory}

The common source of ideas or references is what Jan Assmann (2006) and Danièle Hervieu-Léger (2000) call 'cultural' or 'collective' memory. Both scholars emphasise that memory is culturally transmitted, and is not found only within the individual, but is somehow stored in institutions or texts and, I would add, in relation to the Hindu tradition, also in rituals, behavioural patterns, and ethical conduct, and is shared by a collective of beings in a special setting, situation, and location. This does not indicate that the individual is only part of one collective of being, but it does show that the individual attaches more explicit meaning to some group affiliations than others.

According to Assmann (2006) and Hervieu-Léger (2000), elements of a tradition retained for more than three generations qualify as cultural memory. It does not mean that these supposed core features are not changed or (re)constructed, but rather that, in the minds of the bearers of the tradition, they are understood as essential to their sense of cultural, ethnic, and/or religious belonging. Assmann (2006) differentiates between communicative memory and collective memory, an important distinction in this article. He states that communicative memory occurs in the immediate interaction between people, and does not go back more than three 
generations. The individual's state of mind or emotional state of being plays an important role in communicative memory, because it helps to preserve the content of the experience (love, anger, disillusion, etc. (Assmann 2006: 3 ). However, it does not help to preserve collective memory, which may be transmitted from generation to generation. Therefore, as a survival mechanism in an evolutionary cultural scheme, it is important to store core features of the tradition in the collective memory, since, in contrast to communicative memory, cultural or collective memory goes back in history, and may be stored in either institutions or as text. From Assmann's (2006) point of view, cultural or religious texts are a special class of oral or written texts, which may be recalled, irrespective of time and place. It may be added that these texts continue producing meaning for those who understand themselves as part of a particular group, sharing the same presumed reservoir of meaning provider.

In relation to religion, Assmann (2006) defines cultural memory as an institutionalisation of what he calls 'invisible religion' (with reference to Luckmann's book with the same title from 1967). Invisible religion is understood as the process of individuation, and the formation of a personal self. Assmann (2006) does not reject invisible religion he simply aims to understand why we find the maintenance of symbolic universes over generations, and a continuity of a special system of meaning and identity (2006: 37). What interests me is not so much the maintenance of symbolic universes, but the recalling or awareness of symbolic universes that may be used in the formation or establishment of collective memory.

When it comes to second-generation Sri Lankan Tamil Hindu women in Denmark, they are generally very critical of their parents' relation to collective memory, which they find too narrow, too local, wrongly interpreted, or lacking reflection. These elements are mostly anchored in local Tamil Hindu tradition, tied to a particular locality in Sri Lanka, which does not seem to fit many well-educated, second-generation, Sri Lankan Tamil Hindu women's world- and life-views, which are constructed to fit their new setting, and position in life in Denmark. It is obvious that they do not want to become mono-cultural, but cultural hybrids, taking elements from Tamil Hindu and Danish culture, in a patchwork culture that fits their circumstances - both geographically and in life. This does not mean they reject collective memory, which links them to their parents, but they qualify it so it fits their new setting in a way that may also exist in the future. In that way, it becomes a floating signifier with translocal positionality potential, so it can be meaningful also for the coming generation in a changing world, even if they leave Denmark.

Hinduism is full of superstition. Just look at our parents. As an example, I can tell you that my mother was very engaged in astrology, especially how 
the planets were placed in relation to each other. Sometimes she said: 'now we are facing a bad period'. And we had to fast or we had to go to the temple to make offerings. It was driving me crazy. Today, I have to admit, I look a bit at it myself - but in contrast to my mother, I consult books about the subject. (Sri Lankan Tamil Hindu, woman, 27 years of age).

This statement is an example of how she relates to her parents' tradition, though not without hesitation. She needs proof or a textual authority to support a belief, before she will let it become part of her meaning system, or approve it as part of collective memory. The fact that the Tamil Hindu tradition matters is also expressed by another young Tamil women, who wants to transfer the tradition to her children, but in a changed form:

I don't want my children to become rootless. I do have roots here, but anyway. The Tamil language, but also the temple must play a role. (Sri Lankan Tamil Hindu, woman, 24 years of age).

And of her relationship to the temple, which openly differs to that of her parents:

\begin{abstract}
Hinduism is for me to believe. And I see the temple, when I think of Hinduism. Because it is in the temple I worship, not at home, as my parents do. They have a mandir (altar) at home, I haven't. And the rituals in the temple have an impact on my understanding of being a Hindu, but also when it comes to the ethical aspects and how to behave. In a funny way, I become aware of these aspects in the temple. Even if I don't understand the rituals that are conducted in the temple, they give me some kind of confidence or structure. It relates me to my tradition, and then you are reminded of what to do and what not to do. (Sri Lankan Tamil Hindu, woman, 24 years of age).
\end{abstract}

Using the idea of collective memory as a theoretical framework does not mean that I disagree with Judith Butler, when she argues that gender is a construction, but I especially agree with her when she simultaneously questions the gender construction by asking "to what extent "identity" is a normative ideal rather than a descriptive feature of experience' in this matter (Butler 1990: 23). In other words, the presumed normativity anchored in the collective memory is being negotiated, or interpreted and used in such a way that it still gives meaning to those who relate to it, as something they share. In relation to the theme of this article, it is interesting to decipher how the construction of gender is negotiated or enacted among young, second-generation, well-educated Sri Lankan Tamil Hindu women in Denmark in a way that enables them to cope with their efforts to be modern and independent women following Danish patterns, but without losing their relationship to the Tamil Hindu tradition, which they still find important as a norm-giver, and as an important contribution to the feeling of belonging in a fluctuating life situation, a feeling of belonging that they want to pass on to their children, to some degree. What seems of great 
importance to this group of young Srilankan Tamil Hindu women is that their children become part of Danish society in daily aspects, on the one hand, but on the other hand, become aware of their special cultural and religious roots. Here, it becomes obvious how the westernised conceptions or selection of Hindu concepts and particular worldviews has an impact on what they understand of profound or 'real' Hinduism (yoga, the personal relationship to God, that God may have many different names, etc., without losing their local understanding of belonging to a specific Sri Lankan Tamil Hindu culture (language, particular temple rituals, ethics, gender-specific roles, etc.). The gender roles, which may be called 'implicit religion', seem to be of special importance to the young women when they have children, particularly because they understand themselves, as women, as the primary bearers and transmitters of religious tradition:

\begin{abstract}
It has always been my mother who told me religious stories, and in many ways raised me in the Hindu faith. She was also the one who did the daily puja (worship) at our little mandir (altar) in our home. It is not because my father isn't religious, but it was just not his obligation. Therefore, being a woman, I see it as my obligation to raise the children in the religious faith. I just want to do it in another way than my mother did. It has to fit the Danish society where my children are born. (Sri Lankan Tamil Hindu, woman, 30 years of age).
\end{abstract}

As indicated earlier, I will now give an example of how the dichotomy of being a modern Danish woman, and a Tamil Hindu woman, has started a discussion of how to find the right husband, who can live up to their ideals as independent and aspirational women, and balance that with their need to keep up traditions that link them to their families, to Sri Lanka, to the Tamils, and to Hinduism.

\title{
How to find the right spouse?
}

"Tamil girls beat every record when it comes to educational level and integration in Denmark. But then follows the question: can we find enough well-educated Tamil men for all these Tamil girls, when they are looking for a husband?" (Poster quotation, March, 2009).

This was the main statement and question on a poster, inviting young Tamils and other interested parties to a debate at an event on 8 March 2009 (The International Women's Day), in Aarhus, Denmark, arranged by the individuals behind the Internet chat forums, such as Nizhal.dk, Tamilgirls.dk, Tamil Magazine and the Bridge-builder (in Danish: Brobyggeren). The poster's headline was: Challenges Tamil women meet when choosing a partner. After the above-mentioned introductory question, the poster further asked the following questions:

1) What kinds of opportunities do Tamil girls find on the marriage market? 
2) Do freedom and independence have an impact on Tamil women when choosing a partner? 3) How do parents, society, and unwritten rules have an impact on Tamil women's lives? 4) Does the fact that the women are better educated than the men have an impact on the gender relations? 5) What expectations and demands do modern, independent, and well-educated Tamil women have of their prospective husbands?

Unfortunately, the morning of the scheduled event, it was cancelled because of problems in Sri Lanka, with a flow of refugees from Jaffna to different refugee camps causing new political tensions on the island, but the invitation was published on the Internet, and further elaborated with even more questions, such as: Have Tamil women found a new social status to replace their parents' patriarchal values? Why is it more common for a Tamil woman to marry a Danish man than for a Tamil man to marry a Danish woman? Do we see a pattern in which young Tamil women are increasingly breaking with their parents' values and socioeconomic relations, and marrying for love? Has the concept of love changed? (Questions launched a bit later on the following two web pages or chatgroups: Tamilgirl.dk, Nizhal.dk, 18.4. 2009)6. This started a long, on going debate, both on the Internet in the two above-mentioned chat groups, and in the magazine, The Bridge builder. It also started broader reflection on being a Tamil Hindu woman with a Danish twist among many of my informants. For some, it seems like the situation in Denmark differs from other Sri Lankan Tamil Hindu groups living in the diaspora. This is at least what the following comment from an anonymous woman writing on Tamilgirl.dk demonstrates:

Dear all, I write this comment as a person who has followed the development of the discussion from the side line. I have noticed two different groups of critics [...]. One group argues that the problem does not exist, and criticizes the arrangers for making up a problem. The other group argues that the arrangers are making the problem too vague. They want an even more critical announcement. I think that things are changing quicker in Denmark, in comparison to England and Canada, for example. It is not because the Tamils in Denmark are more 'humane', but because we are a small community. It is more difficult for a small community to reproduce and keep its values in their original form. In England and in Canada, Tamils do mostly marry within the same caste, and they mostly interrelate with Tamils within the same caste. At the same time, they also marry within their own educational levels. Both are possible in big communities.

In 2005, around $16 \%$ of all Tamil marriages were mixed marriages between a Tamil (mostly women) and an ethnic Dane (source: the Ministry for Integration). ${ }^{7}$ I have been told by some of the Tamil women that it was

\footnotetext{
${ }^{6}$ Both homepages are under reconstruction and for the time being not accessible. I tried to access 10 October 2015.

7 The young woman refers to the following research by Statistics Denmark, Table 2: Education among 16-29-year-old women and men from Sri Lanka in 2007.
} 
because they never met any Tamil men while studying (tamilgirl.dk 2009). ${ }^{8}$

In her comparison of the situation in England and Canada with that in Denmark, she emphasizes that the 'right' match, with respect to caste and educational level, is possible there, but not in Denmark. At the same time, in using the word 'humane', she insinuates a criticism of the way things are done in Canada and England, but without suggesting that the Danish model is ideal. This is also expressed in the concluding paragraph, referring to the fact that an ethnic Danish husband was chosen by Tamil women not because he was an ideal match, but because they never met Tamil men matching their educational level while studying.

With regard to mixed marriages, most of the second-generation Sri Lankan Tamil Hindu women I have interviewed have mixed feelings. One the one hand, they are attracted to the idea, on the other hand they do not think it will turn out well in the long run. This is especially questioned in relation to children, whom they do not want to 'become rootless'

Regarding to the traditions they share with their parent's one interviewee said, this 'has formed me to become the person I am today'. This underlines the fact that connecting to tradition matters, but when it comes to disconnecting, it becomes obvious that most of the second generation of Sri Lankan Tamils ${ }^{9}$ would like to get rid of caste as a parameter determining whom to marry. This is also what the implicit criticism of Canada and England hints at. Instead, the second generation of Sri Lankan Tamil women would like for a new hierarchical system to be considered, namely that of educational achievement. What is of interest here in relation to tradition or collective memory, is that young Sri Lankan Tamil Hindus I have interviewed seem to find arguments within their traditions that align educational levels with caste. They refer - at least indirectly - to purushaartha, the four goals in life that are part of the Hindu ethic, and underline the need for engaging with life. These four goals are dharma (ethics, morality), artha (wealth, political power), kama (erotic and aesthetic enjoyment), and moksha (liberation from reincarnation). Each is related to the others, and to the four ashramas (life stages). Even the fact that the specific rituals required for each life goal is seldom followed by the Tamil Hindus in Denmark ${ }^{10}$, does not mean that the implicit goals are not. This have become clear in my interviews where the young Tamil Hindu women somehow manage to make these four goals becoming an argument, when discussing their strives in life. In particular, artha is used to legitimize

\footnotetext{
${ }^{8}$ The homepage is under reconstruction and is for the time (17 October 2015) being not available.

${ }^{9}$ It shall be noticed that the caste system is also in play when it comes to the smaller group of Catholic Srilankan Tamils in Denmark. So they were part of the discussion.

${ }^{10}$ The four life stages are as brahmacharya/brahmacharin (student), as grihastha/grihini (housekeeper), vanaprastha (wanderer in the forest), samnyasin (ascetic).
} 
engagement with a modern society, because it is interpreted as emphasizing education, ultimately leading to a prestigious job, as its fulfilment. The other three goals are also taken into account. Dharma in relation to their emphasis on how they want to be good and decent Danish citizens, who can contribute to the Danish welfare state. Kama, they relate to their hope for finding a husband that suits them both intellectually and socially; and moksha, the final goal in the Hindu soteriology, they think in some ways fits to the idea of reincarnation - something that have a positive appeal to many people in Denmark with a Danish descent. So, in that way, their negotiating is not a question of dismantling tradition, but a question of adapting it to their lives in Denmark. This is also sometimes combined with references to some of the goddesses in Hindu mythology, such as Parvati and Sita, who, as mothers, nurturers and wives, but also as yielders of power in their own right, (Shakti) can be role-models for young well-educated Hindu woman in Denmark.11

\section{Conclusion}

Young Sri Lankan Tamil Hindus who are either born in Denmark or came to Denmark when they were small children, have a different relationship to their traditions when compared to their parents. This is not a new observation but what I have tried to show in this article is that their selfunderstanding as young Sri Lankan Tamil Hindu women balances the encompassing and renewing of elements from their tradition in a way that it still is understood as a 'collective memory' they share with their parents, and at the same time, accommodates their lives in Denmark, as modern and independent women. Ideally, as having job, getting children and having a husband, who supports her in her civilian career.

Through my interviews with well-educated second-generation Sri Lankan Tamil Hindu women in Denmark, it has become obvious that not only do the language, religious texts, and the temple institution play important roles in preserving their traditions, but they also associate these traditions to their self-identity as Tamil and/or Hindu which they wish to pass on to their children. I have given the example of how, by referring to purusha-artha, they argue for taking educational attainment into account, instead of caste, when finding the right spouse, but it is also notable to mention how parts of Hindu mythology that describe the goddesses as both ideal mothers and wives, and as independent figures, are used in arguments by my informants. For instance they refer to some of the stories of the goddess Parvati and her relation to the God Shiva. This suits well to Mandakranta

\footnotetext{
${ }^{11}$ Bose identifies the kinds of ideals that nurture the conceptions of the female gender, their assigned roles, and the treatment of women in Hindu society. This influences the archetype model, which distinguishes between the following four types: 1) mother/nurturer; 2) wielder of power/protector; 3 ) wife/helper/daughter; 4) destroyer.
} 
Bose overall analysis on the meaning of Hindu goddesses of today, where she emphasise how the goddesses function both as philosophical and social archetypes (Bose 2010: 13).

The foregoing are examples of how young Sri Lankan Tamil Hindu women reinterpret or pick out elements from what they understand as tradition, which helps them to engage in the society in which they are now a part of, and at the same time, links them to what they consider as a collective memory that they share with their parents. Something, if not everything, changes in a new setting (adaptation), but from these women's perspectives, only to a certain extent, and without losing what seem to be core features within the same tradition (preservation). Thus, collective memory, understood as a shared belonging to a specific group, despite its constantly changing form, may still be understood as the custodian of a presumed, mutually shared tradition.

The need to keep up a presumed shared tradition in a new setting and under new circumstances makes these well-educated Tamil Hindu women question how to find a husband in Denmark. They both want a man who can live up to a certain educational level, and at the same time they want him to have the same references to the parts of the Sri Lankan Hindu Tamil tradition, which they find important to transfer to their own children. Here, the Tamil language and having some kind of relation to the Tamil Hindu temple and to some of the festivals is emphasized as having special importance for them.

In the case of the Sri Lankan Tamil Hindus in Denmark, encountering a country with an implicit secularization paradigm starts a process of a more profound or reflected exclusion and inclusion of elements within a presumed, mutually-shared collective memory. This is done in a way so it suit their lives in Denmark, but without they loose their relation to the traditions they somehow share with their parents and which link them to a mutually shared descent.

This construction of a specific Hindu, Tamil, Sri Lankan, Danish, female identity, they hope can be accepted as something valuable, both among other Sri Lankan Tamil Hindus in Denmark, and the Danish society at large.

In many ways, this effort goes hand in hand with the concept of cultural hybridisation, suggesting that identity and culture are generated by a crosscultural or multi-dimensional communication. The constructed meeting point that Bhabha (1994) calls a third space, both contain elements of and differ from the 'original' cultures. This meeting point is never fixed, but comprises heterogeneous elements with shifting points of view. In this way, cultural hybridity is continuously constructed, and is a product of an on 
going process of negotiation and identification, formed in relation to context, and from different points of departure. However, because the meeting point is lifted out of the locality in which the negotiations took place beforehand, it may be more suitable to use the concept of 'translocal positionality', emphasising the even more complex and multifarious nature of identity formations. What I have tried to show in this article having the second generation of Sri Lankan Tamil Hindu women as my case study is how this complexity is coped with, by focusing on but also by refining to the imagined idea of a mutually-shared, collective memory which are located in rituals and texts and therefor possible to move to new localities shaping a constructed translocal focus point. This was illustrated in this article by the Sri Lankan Tamil Hindu women's strive for finding some important, mutually-shared, cultural hallmarks to be preserved and passed on to their children. Here, the religious institution, some few rituals, and the language, seem to have particular importance but only as long they do not intervene with their new ideals being and independent woman living in Denmark.

\section{References}

Alter, Joseph (2004) Yoga in Modern India: The Body between Science and Philosophy. Princeton: Princeton University Press.

Amarnath, Amarasingam (2015) The Cultural, the Nominal, and the Secular: The Social Reality of Religious Identity Among Sri Lankan Tamil Youth in Canada. In Beaman, Lori \& Tomlins, Steven (eds.), Atheist Identities - Spaces and Social Contexts. Heidelberg, New York, London: Springer.

Assmann, Jan (2006) Religion and Cultural Memory. Stanford: Stanford University Press.

Bauman, Zygmunt (2000) Liquid Modernity. Cambridge: Polity Press.

Beckford, James (2003) Social Theory \& Religion. Cambridge: CUP.

Beyer, Peter (1994) Religion and Globalization. Canada: Sage Publications Ltd.

Bhabha, Homi (1994) The Location of Culture. London: Routledge.

Bharati, Agehananda (1970) The Hindu Renaissance and its Apologetic Patterns. The Journal of Asian Studies, 29 (2), 267-287.

Bhatia, Sunlil \& Ram, Anjali (2004) Culture, Hybridity and the Dialogical Self: Cases from the South Asian Diaspora. Mind, Culture and Activity 11(3), 224-240. 
Bose, Mandakranta (2010) Women in the Hindu Tradition: Rules, roles and exceptions. London and New York: Routledge.

Bramadat, Paul (2005) Beyond Christian Canada: Religion and Ethnicity in a Multicultural Society In Bramadat, Paul \& Seljak, David (eds.), Religion and Ethnicity in Canada. Toronto: Pearson Education.

Breton, Raymond (2012) Different Gods. Integrating Non-Christian Minorities into a Primarily Christian Society. Montreal \& Kingston: McGillQueen's University Press.

Butler, Judith (1990) Gender Trouble: Feminism and the Subversion of Identity. New York and London: Routledge.

Campbell, Colin (2007) The Easternization of the West. A Thematic Account of Cultural Change in the Modern Era. London: Paradigm Publishers, Boulder.

Connerton Paul (1989) How Societies Remember. Cambridge: CUP.

Csordas, Thomas J. (2007) Modalities of transnational transcendence. San Diego: University of California Press.

Csordas, Thomas (2009) Transnational transcendence: Essays on Religion and Globalization. Berkeley: University of California Press.

Denmarks Statistic (2014). Indvandrere $i$ Danmark. Avaiable at: http:/ / www.dst.dk/Site/Dst/Udgivelser/GetPubFile.aspx?id=19004\&sid= indv [accessed: 18.10.2015].

Dwyer, Rachel (2004) The Swaminarayan Movement. In Knut A. Jacobsen and Pratap P. Kumar (eds.) South Asians in the Diaspora: Histories and Religious Traditions. Leiden: Brill, 181-99.

Fibiger, Marianne Qvortrup (2012) When the Hindu-Goddess Moves to Denmark: The Establishment of a Sakta-Tradition. BSR 41(3), 29-36.

Fibiger, Marianne Qvortrup (2010) Young Tamil Hindus in Denmark and Their Relationship to Tradition and Collective Memory. FJEM 5(2), 24-32.

Flood, Gavin (1996) An Introduction to Hinduism. Cambridge: Cambridge University Press.

Frazier, Jessica (2011) (ed.) The Continuum Companion to Hindu Studies. London: The Continuum International Publishing Group. 
Frøystad, Kathinka (2009) The Return Path: Anthropology of a Western Yogi. In Thomas J. Csordas (ed.) Transnational Transcendence: Essays on Religion and Globalization. Berkeley: University of California Press.

Giddens, Anthony (1991) Modernity and Self-Identity. Cambridge: Polity Press.

Goldberg, Philip (2010) American Veda: From Emerson and the Beatles to Yoga and Meditation How Indian Spirituality Changed the West. USA: Random House LLC.

Halbwachs, Maurice (1952) Les Cadres sociaux de la mémoire. Paris: PUF.

Heelas, Paul (2008) Spiritualities of Life. Oxford: Blackwell.

Heelas, Paul \& Woodhead, Linda (2005) The Spiritual Revolution. Why religion is giving way to spirituality. Oxford and Victoria: Blackwell.

Hervieu-Léger, Danièle (2000). Religion as a Chain of Memory. Cambridge: Polity Press.

Hole, E. (2001) Ethnicity and symbolism among Hindu women in a small diaspora community. In T. S. Rukmani (ed.), Hindu diaspora: global perspectives. New Delhi: Munshiram Manoharlai, 443-469.

Jacobsen, Knut A. (2004) Establishing Ritual Space in the Hindu Diaspora in Norway. In Knut A. Jacobsen \& Pratap P. Kumar (eds.), South Asians in the Diaspora: Histories and Religious Traditions. Leiden: Brill, 134-48.

Jenkins, Richard (2003). Rethinking Ethnicity. London: Sage.

Kapadia, Karin (1996) Dancing the Goddess: Possession and Class in Tamil South India. Modern Asian Studies 30 (2), 423-445.

Kinsley David (1987) Hindu Goddesses. Visions of the Divine Feminine in the Hindu Religious Tradition. Delhi: Motilal Banarsidass.

Knott, Kim (2000) Hinduism in Britain. In H. Coward \& J. Hinnels \& R. Williams (eds.), The South Asian diaspora in Britain, Canada and The United States. Albany: New York State University Press, 89-108.

Knott Kim (1996) Hindu women, destiny and streedharma. Religion 26, 1535 .

Leslie Julia (ed.) (1991) Roles and Rituals for Hindu Women. London: Pinter. 
Levitt, Peggy (2007) God Needs No Passport: Immigrants and the Changing American Religious Landscape. New York: New Press.

Lipner, Julius (2010) Hindus their religious beliefs and practices. London and New York: Routledge.

Lorenco, I. (2011) Religion and gender: the Hindu diaspora in Portugal. South Asian Diaspora, 3(1), 37-51.

McGuire, Meredith B. (2008) Lived Religion: Faith and Practice in Everyday Life. Oxford: Oxford University Press.

Menon, Usha (2002) Making sakti: Controlling (Natural) Impurity for Female (Cultural) Power. In Ethos 30(1/2), 140-157.

Ministry of Justice Website (2015). God integration fører til statsborgerskab. In the Justice Minister Website [Online, 23 May 2013]. Avaiable at: http://www.justitsministeriet.dk/nyt-og-

presse/pressemeddelelser/2013/god-integration-fører-til-statsborgerskab [accessed: 19 October 2015].

Michaels, Axel (1998) Der Hinduismus: Geschichte und Gegenwart. München: Verlag C. H. Beck.

O'Flaherty, Wendy Doniger (1980) Women, Androgynes and Other Mythical Beasts. Chicago and London: University of Chicago Press.

Rayapol, A. (1997) Negotiating identities: women in the Indian diaspora. New Delhi: Oxford University Press.

Rayapol, A. (1995). Gender ideologies and practices among South Indian immigrants in Pittsburgh. Sagar: South Asian Graduate research Journal, 2 (1) 268-270.

Sen, Amartya (2000) Social Exclusion: Concept, Application, and Scrutiny. Social Development Papers No. 1, Office of Environment and Social Development Asian Development Bank. Manila: Asian Development Bank.

Sharot, Steven (2001) A Comparative Sociology of World Religions. New York: New York University Press.

Singleton, Mark (2010) Yoga Body: The origins of modern posture practice. Oxford: Oxford University Press.

Swamy, M. R. Narayan (1994) Tigers of Lanka: From boys to guerillas. Colombo: Vijitha Yapa. 
Swamy, M. R. Narayan (2003) Inside an elusive mind: Prabhakaran. Colombo: Vijitha Yapa.

Tsing, Anna Lowenhaupt (2005) Friction. Princeton: Princeton University Press.

Vertovec, Steven (1990) Religion and Ethnic Ideology: The Hindu Youth Movement in Trinidad. Ethnic and Racial Studies, 13 (2), 223-49.

Woodhead, Linda \& Heelas, Paul (2000) Religion in modern times: an interpretive anthology. London: Blackwell Publishing LTD. 